\title{
Exercises to Boost Self-Esteem and Self-Realization
}

\section{Mayumi Hamada \\ The University of Marketing and Distribution Sciences}

\section{Reference Data:}

Hamada, M. (2019). Exercises to boost self-esteem and self-realization. In P. Clements, A. Krause, \& R. Gentry (Eds.), Teacher efficacy, learner agency. Tokyo: JALT.

https://doi.org/10.37546/JALTPCP2019-36

This paper introduces some enjoyable and effective English exercises used in a 2016 content and language integrated learning (CLIL) course that combined career education and English and language integrated learning (CLIL) course that combined career education and English
learning. It also elaborates on the concept of selective attention, the theoretical rationale behind the effectiveness of the exercises. Exercises based on selective attention were designed to train students on how to shift their focus from negative thoughts and feelings such as complaints, anxieties, and regrets, to positive thoughts and feelings such as hopes, dreams, success and happiness. Hamada (2018) found that this 2016 CLIL course significantly enhanced the students' self-esteem and had a positive effect on their mental attitudes toward life. This paper will also discuss how the exercises based on selective attention influenced the findings of the 2018 study. 本稿では、キャリア教育と英語学習を統合した2016年の内容言語統合型学習 (CLIL) コースで使用された効果的で楽しい 英語エクササイズを紹介し、その効果の理論的根拠である「選択的注意」という概念について述べる「選択的注意」に基づい たエクサイズは、脳のフォーカスが不満、不安、後悔といった否定的思考及び感情から希望、夢、成功、幸福といった肯定的思 考や感情にシフトされるようにデザインされた。濱田(2018)の研究によると、2016年のCLILコースは受講者の自尊感情を高 め、人生に対する考え方に肯定的な变化を屯たらす効果があることが明らかになった。本稿では、「選択的注意にに基づいたエ クササイズが2018年の研究結果にどのように影響を与えたかについても考察する。

he International Survey of Youth Attitudes conducted by the Cabinet Office in 2013 revealed that Japanese young people had lower self-esteem and less hope about their future compared with six other developed countries (International Survey of Youth Attitudes 2013,2014). The purpose of the survey was to identify the attitudes of young people in Japan and six foreign countries (Korea, the United States, the United Kingdom, Germany, France and Sweden), and analyze the characteristics of Japanese youth.

To tackle this situation, the Ministry of Education, Culture, Sports, and Technology (MEXT) started to promote career education in school curriculums. One of the categories focused on was developing the abilities needed to understand and manage one's self, such as the ability to take positive, proactive steps, take into account future potentials, keep looking forward, remain self-motivated, and be proactive (MEXT, Guidance for promoting career education, 2006). The Japan Association of National Universities also emphasized the importance of having dreams and goals, creating a career vision, and achieving self-realization (The Current State of Career Education at Japanese Universities, 2009).

\section{A Unique CLIL Course}

In order to promote career education implemented by MEXT, a unique CLIL course combining self-realization and English learning was offered at the University of Marketing and Distribution Sciences in 2016. CLIL is a "dual-focused educational approach in which an additional language is used for the learning and teaching of both content and language" (Mehisto, Marsh, \& Frigols, 2008, p. 9). CLIL is considered to be a beneficial approach in several ways (Izumi, lkeda, \& Watanabe, 2012; Mehisto et al., 2008). For example, proponents argue that CLIL can increase student motivation, foster thinking skills and promote cognitive flexibility, encourage interactions among students, provide meaningful input, and improve linguistic competence, just to name a few (lzumi, et al., 2012; Mehisto, et al., 2008). Another important advantage attributed to CLIL is flexibility in language usage. That is, the proportion of the use of the first and target languages can be adjusted according to the students' level or the difficulty of the content. Since the CLIL course also included some abstract theoretical concepts in cognitive neuroscience, flexibility in the use of both languages was deemed especially beneficial. 
The course had two main objectives: 1) to enhance the students' self-esteem and selfrealization and 2) to develop the students' motivation to learn English. It was offered as an elective English class, and 30 students registered. A 90-minute lesson was conducted once-a-week for 15 weeks. Since the students' TOEIC scores varied widely from 300 to 800 , both English and Japanese were used in class, depending on the difficulty of the content.

The lesson plans were designed to cover the four components of the CLIL course: content (subject matter), communication (language learning), cognition (learning and thinking process), and community/culture (learning together and developing intercultural understanding). When applied to the context of this course, these terms specifically refer to the following:

- Content: Learning about the mind, discovering dreams, clarifying specific goals

- Communication: Practicing the four skills of English

- Cognition: Reflecting on and gaining a deeper understanding of oneself

- Culture: Understanding others through sharing, discussion, mini speeches and presentations

Each lesson consisted of a mini lecture and a few English exercises. In the mini lectures, the students learned basic concepts and characteristics of the conscious and unconscious mind. By understanding the potential of the unconscious and how to make use of the two-track mind (conscious and unconscious), the students could become more aware of their untapped potential and become better able to reach their self-realization goals. After the 30-minute mini lectures, the students were given about one hour to engage in exercises which were aimed at changing their perspectives on life in addition to the language objectives.

To examine the effectiveness of the CLIL course, a questionnaire in Japanese using a 5-point Likert scale was conducted at the beginning and the end of the course. The questionnaire consisted of 43 questions in three categories: items that measure selfesteem, those that measure attitudes toward life, and ones to measure motivation for learning English. Ten questions measuring self-esteem were adapted from Yamamoto, Matsui, and Yamanari (1982), 28 items assessing attitudes toward life were adapted from Itazu (1992), and five items evaluating motivation for learning English were designed originally by this writer (see Appendix A).

The questions asked students to answer on a Likert scale ( 1 = strongly disagree, $2=$ generally disagree, $3=$ neither agree nor disagree, $4=$ generally agree, $5=$ strongly agree). Data from the 22 students who completed the course and answered both questionnaires was used for analysis. A paired-samples $t$-test was conducted for each category to compare the scores at the beginning and the end of the course. In order to collect additional feedback, the students were instructed to reflect on the course and write any thoughts and feelings freely, either in English or Japanese, at the end of the semester.

Answers to questions about self-esteem indicated a significant increase between the scores at the beginning $(M=32.14, S D=7,815)$ and the end $(M=34.73, S D=8.282)$; $t(21)=2.997, p=0.007$. Answers to questions about attitudes toward life also showed a significant increase between the scores at the beginning $(M=105.05, S D=14.650)$ and the end $(M=108.82, S D=17.300) ; t(21)=2.008, p=0.049$. Answers to questions about motivation for learning English did not show a significant difference between the scores at the beginning $(M=21.50, S D=2.632)$ and the end $(M=21.59, S D=2.576) ; t(21)=$ $0.289, p=0.776$

The overall results indicate that the 2016 CLIL course successfully enhanced the students' self-esteem and their attitudes toward life. To elaborate on Hamada (2019), this paper will focus on the exercises used in the 2016 CLIL course, describe the concept of selective attention, and discuss how the exercises could help enhance the students' selfesteem and attitudes toward life. Some of the exercises will also be presented in detail.

\section{The Concept of Selective Attention}

Selective attention is the focusing of our conscious awareness on certain sensory information while ignoring other stimuli outside our awareness. According to Wilson (2002), our five senses take in around 11,000,000 pieces of information per second,

and we can consciously process only about 40 of them. This selection process, which is necessary to prevent our senses from being overloaded, is done by a nonconscious filter in our brain. The filter examines incoming stimuli from our senses and decides which information will get access to our consciousness. Taking in 40 out of 11,000,000 means we can consciously perceive only $0.00036 \%$ of incoming information. How then does the nonconscious filter work?

First, our brain detects what we consciously pay attention to. Research on selective attention has shown we can successfully catch only the information we pay attention to (Cherry, 1953; Dalton \& Fraenkel, 2012; Simons \& Chabris, 1999). For example, if you decide to buy a yellow car, it is likely you will start to see yellow cars more often. It seems that the number of yellow cars has suddenly increased although the actual number remains the same. This is because the nonconscious filter selects the type of car you want and brings it to your awareness while filtering out other types of cars. 
Selective attention also functions for unattended information in case it is "important" to us. According to Moray (1959), participants in a research study recognized their names although they were instructed to concentrate on other information. This occurs in everyday life. For instance, imagine you are absorbed in a conversation with a friend at a big, noisy party. When your name is suddenly called from somewhere, the voice comes into your ears immediately although you are not paying attention to it. Since your name is important and relevant information, your nonconscious filter scans it immediately from all the surrounding sounds and brings the unattended voice to your conscious attention.

Furthermore, the information selected by the nonconscious filter depends on how often a thought has been used in the past (Wilson, 2002). This means that a repeated thought, whether it is positive or negative, constructive or destructive, happy or unhappy, will be considered "important" by the brain. Accordingly, the nonconscious filter will select relevant information based on that thought and will bring it to your awareness. That is why some people see an opportunity while others see a problem in the same situation. Our perception is determined by the information selected by the filter Hence, our perception can change completely depending on what the filter chooses.

In short, the "world" we consciously perceive is controlled by an extremely small portion of the information that our nonconscious filter selects. If a large portion of that information is negative, destructive, and unhappy, the world will be experienced that way. If the information sent to awareness is positive, constructive, and happy, the opposite will happen. The information selected by the nonconscious filter shapes our perceptions, which influence our emotions and thoughts.

This being the case, how can we consciously get the nonconscious filter to choose useful information on what we want and filter out what we do not want? One possible way is to repeat paying attention to what we do want so that our brain recognizes it as important. Then the nonconscious filter will automatically start to select "what we want" and bring it to our awareness.

We live in an information age and are flooded with a great amount of sensory input. It is inevitable that we get exposed to a large amount of negative and depressing information such as crime, war, terrorist attacks, economic depression, and environmental destruction. In such a media environment, it is not easy to keep our focus on hopes and dreams. Thus, it is important to teach students how to carefully choose what they pay attention to.

\section{Methodology}

The concept of selective attention was applied to the design of the exercises used in the 2016 course. The purpose of these exercises was to change the students' life perspectives. Activities were developed to train the brain to shift focus from negative thoughts and feelings such as complaints, anxieties, and regrets, to positive notions of hopes, dreams, success, and happiness.

In each class, students spent about one hour working on a few selective attention exercises. The frequency and duration of each one varied. Some were used regularly in every class, while others were used once, depending on their content or length.

Exercises were also given as homework every week so the students could spend enough time turning their thoughts inward and self-reflecting before sharing their answers with their classmates in class. Since the students' levels varied widely, and some exercises were too difficult for lower-level students to answer directly in English, the students were allowed to write their answers in Japanese and then translate them into English. In the next class, they were ready to share their answers orally in English with their classmates and could reinforce what they had written by reading it aloud. A private Facebook (FB) group was also used for some exercises so that the students could share their answers with their classmates.

\section{Exercises Based on Selective Attention}

The following are some examples of exercises designed based on selective attention, including how they were used in the 2016 course.

\section{Good and New}

Good and New is a one-minute speech practice activity. The students have to think back through the week and remember a good or a lucky event. When this exercise is introduced, it is explained to the students that both good and bad things happen in everybody's life. Happy people pay attention to positive events amidst adversity, while unhappy people tend to focus on something they do not want. In the 2016 course, this exercise was introduced at the beginning of the semester. It was given as a homework assignment and shared orally in pairs in the next class. The students were required to do this exercise every week throughout the course. 


\section{Gratitude List and Arigato (Thank You) Counter}

In this exercise, the students have to find something they are grateful for, fill out a gratitude list, and write English sentences (see Appendix B). When sharing their list with classmates, they use an Arigato Counter (Uchida, 2014), a clicker device which tracks the number of times arigato is uttered (see Figure 1).

The Arigato Counter is a fun and happiness-inducing tool. Students count how often they say arigato in pairs and groups. This tool can instantly change the energy of a class and create a positive and happy atmosphere.

It also increases motivation because every time the students say arigato, they click the counter, and the number increases. Since the total number of utterances is visible, students are incentivized to continue expressing gratitude.

In the 2016 course, the Arigato Counter was distributed to students in the middle of the semester. Making a gratitude list was first given as a homework assignment, and the counter was distributed in the next class. After receiving instruction on how to use it, they were put in pairs and counted arigato instances while looking at their gratitude list. From the following week, they used the Arigato Counter without relying on their list. They tried to come up with as many reasons to say arigato as possible and shared their ideas with classmates for about 10 minutes. This exercise was conducted every week until the end of the semester.
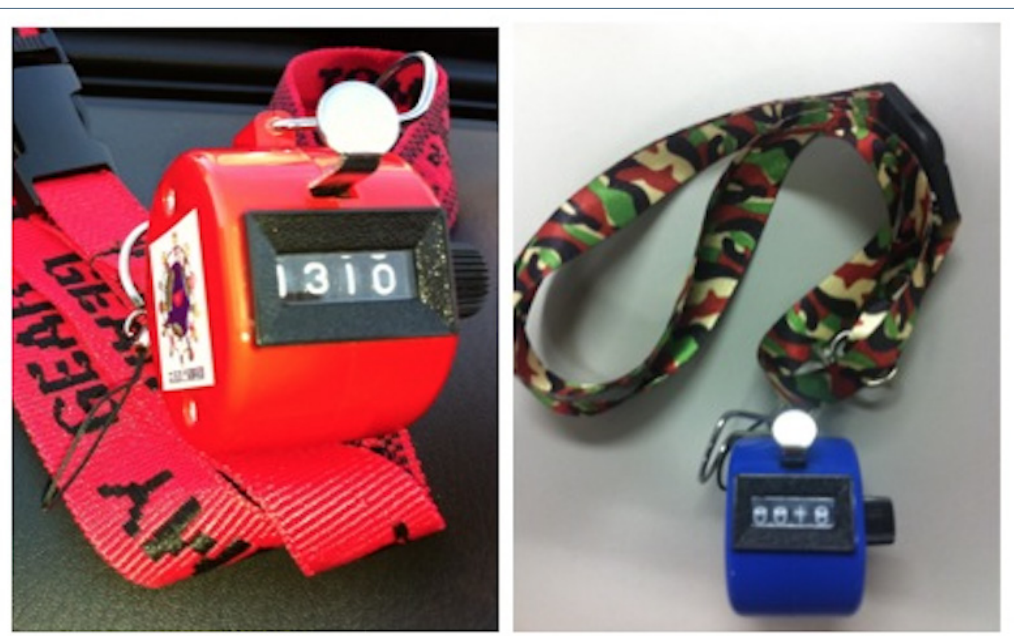

Figure 1. Arigato counter.

\section{Twenty-Five Places I Plan to Visit}

In this exercise, students are required to write 25 places they would like to visit and what they would like to do there (see Appendix C). The 25 places can be somewhere in Japan or other countries. It is difficult for most of the students to come up with as many as 25 places right away. As a result, students are required to do some information gathering. For example, they can visit a travel agency and get a variety of travel brochures before completing their list. This task can help students learn about wonderful places they did not know and stimulate their motivation. It can also provide more detailed information about the places they already have interest in. Next, students bring their list and travel brochures to class and share the 25 places they chose with their classmates in pairs. Every time students hear an unknown place, they ask their partner about it and get information about it. If they are interested, they can add it to their own list. When they are asked about a place on their list by their partner, they must show a picture of it from a travel brochure and provide additional explanation.

In the 2016 course, this exercise was used over a 3-week period. It was introduced to the students in the first lesson, and completed at home by the second lesson. In that lesson, students shared their answers with classmates. In the third lesson, they gave a short speech about one of the places on their list.

\section{Treasure Map}

The Treasure Map activity consists of a board or paper upon which a collection of photos, images, illustrations, and phrases representing a person's dreams and goals are displayed (see Figure 2). This display helps clarify and visualize specific goals and dreams and has been used for career education in Japan (Chiba Nippo, 2013; Watanabe, 2006). Research shows that setting clear goals helps people live longer and healthier lives (Hill \& Turiano, 2014). In order to make a Treasure Map, students are required to reflect on their personal interests, discover their dreams, and clarify their specific goals through exercises such as brainstorming, information gathering, reading relevant books, and sharing ideas with classmates. 


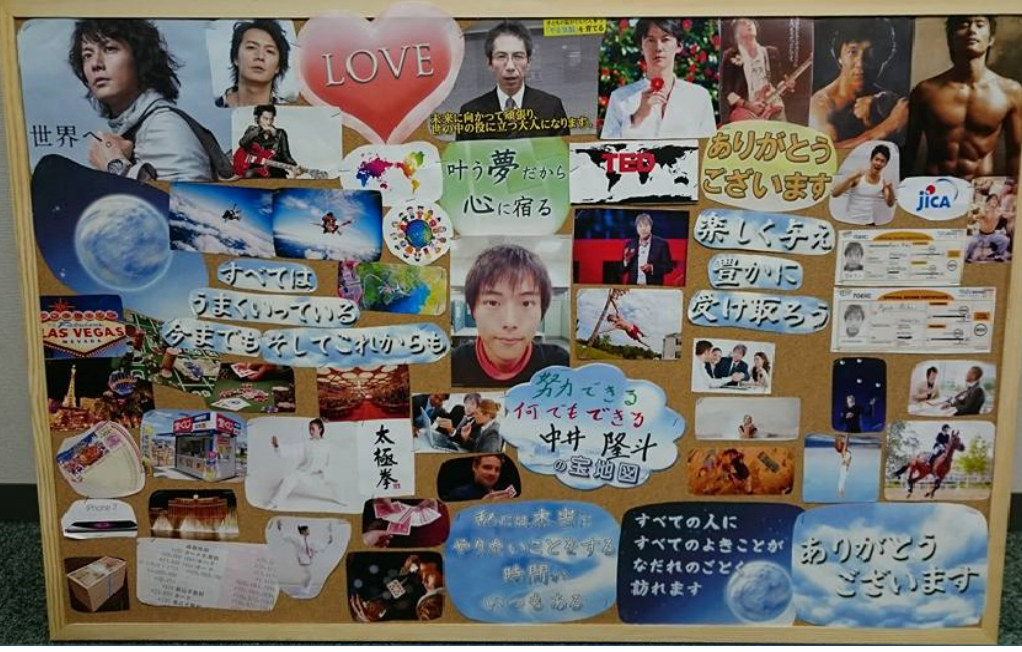

Figure 2. Sample student treasure map.

In the 2016 course, the Treasure Map was used as the final project. The students spent two whole class periods making their individual maps. The following three class periods were used for presentations. Each student gave a short presentation (5-10 minutes) about their dreams and goals in English in front of the whole class. After each presentation, the audience members wrote positive feedback on a post-it and gave it to the presenter. After the presentation, the students were instructed to put their Treasure Map in a prominent place in their homes so they could be reminded of their dreams daily. They were also asked to post a picture of their Treasure Map in the class Facebook (FB) group and show where in their home they displayed it. Finally, they were encouraged to post a comment whenever one of their dreams came true.

\section{Discussion}

As mentioned earlier, the 2016 CLIL course was found to have significantly enhanced the students' self-esteem and attitudes toward life (Hamada, 2018). Although it is not certain exactly which aspects of the course did this, it can be assumed that some connection exists between the results and exercises.

Various changes in the students were observed over the length of the course. For example, there were some who could not complete Good and New at the beginning due to a reported inability to recall anything good or lucky. However, by the end of the course, most students could complete this activity without difficulty. Repeated practice in cultivating positivity and gratitude seems to have played a role in this change.

As for the Arigato Counter exercise, towards the end of the semester the students were able to count more utterances of arigato more easily. The purpose of this activity was to help redirect awareness from what they thought is missing from their life to what they already have. The Arigato Counter seems to be an effective brain-training tool because it provides a lot of sensory information to the brain: there is the visual sensation of seeing the number on the counter, the tactual sensation of clicking the counter with their fingers, an auditory sensation of hearing the clicking sound, and their own voice expressing words of gratitude. Using the Arigato Counter in every class appears to have helped the students' nonconscious filter select what they can be grateful for. Consequently, their perception of reality may have changed as their gratitude increased, which in turn may have resulted in enhancement of self-esteem and positive attitudes toward life.

In the Twenty-Five Places I Plan to Visit activity, some students even reported taking action by visiting some of the places they included in the exercise. How can such behavior be explained? One possibility is that when students introduced a place using visual and auditory information, a feeling of excitement was generated, thus allowing the nonconscious filter to bring relevant information to their awareness, thus leading them to actually perform the necessary actions.

Regarding the Treasure Map, several students reported to the FB group that some of the dreams they had displayed had come true. It seems as though the process of collecting photos and articulating dreams served to maintain their focus on ideal futures. A considerable amount of information about their dreams seems to have been sent to their brain. The nonconscious filter may have been "programmed" to select useful information for realizing their dreams. Looking at their maps constantly may also have helped keep their attention focused on their dreams and encouraged realization of some of them.

Changes in the students' attitudes were also seen in their comments collected at the end of the course. For example, 13 out of 22 students wrote about positive changes in their feelings and ways of thinking, such as "I can take things more positively than before" and "I became more optimistic". There were comments concerning gratitude such as "I feel happier and more grateful" and "I shouldn't forget a feeling of gratitude". Some students also commented on their dreams and actions: "I did not think I had so many dreams", "I was able to clarify my dreams and goals", and "Taking action is very

M FRONT PAGE 
important". These comments suggest that the students' focus shifted so that they were able to see more opportunities, possibilities, and hope.

The length of time the students spent on the exercises may have also influenced enhancement of their self-esteem and attitudes toward life. In fact, students spent one hour in every lesson and some additional time outside class on the exercises. As a result, they were constantly paying attention to what they wanted. As Wilson (2002) pointed out, repeated thoughts will be considered "important" by the brain. By doing the exercises for 15 weeks, the students might have trained their brain to recognize information about what they want as "important". As a result, information selected and brought to awareness by their nonconscious filter changed, and their perception of themselves and the "world" seems to have become more positive, thus leading to enhancement of self-esteem and positive attitudes.

One limitation of this study centers on whether the successful performance of the exercises accurately demonstrates actual changes in self-esteem or life attitudes. It is possible that the students became capable of finding positive aspects in their lives not because their attitudes were enhanced, but because they simply got better at understanding and performing the exercises. More research is needed to clarify exactly how the exercises influenced the students' outlooks.

\section{Conclusion}

This paper has introduced some enjoyable English exercises used in a 2016 CLIL course which combined career education and English learning. Various activities were designed to help shift attention to positive aspects of life and enhance self-realization. The paper has also elaborated the concept of selective attention, upon which the design of the exercises was based. This study has suggested that the exercises based on this concept positively changed the students' perspectives and attitudes about their lives. It also implied that the sustained attention on gratitude cultivation may have helped enhance the students' self-esteem as well. The exercises introduced in this paper can be adapted and expanded for different teaching contexts. It is hoped that many more enjoyable and effective activities based on selective attention will be developed and that the kind of CLIL course demonstrated herein will be adopted to help more Japanese young people make better use of their abilities, take proactive action, and achieve self-realization.

\section{Bio Data}

Mayumi Hamada is an associate professor at the University of Marketing and Distribution Sciences in Kobe. Her current research interests include CLIL, learner autonomy, implicit learning, and learning motivation. She is also interested in positive psychology and cognitive neuroscience, on which basis she is currently developing English teaching materials. She is the co-author of textbooks in the Macmillan Cinema English series and Grammar Network by Cengage. <Mayumi_Hamada@red.umds.ac.jp>

\section{References}

Cherry, E. C. (1953). Some experiments on the recognition of speech, with one and with two ears. The Journal of the Acoustical Society of America, 25(5), 975-979. https://doi.org/10.1121/1.1907229

Dalton, P. \& Fraenkel, N. (2012). Gorillas we have missed: Sustained inattentional deafness for dynamic events. Cognition, 124(3), 367-372. https://doi.org/10.1016/j.cognition.2012.05.012

Hamada, M. (2018). 大学英語授業における「宝地図」活用法に関する研究 (2) [Research on integrating Treasure Map into a college English course (2)]. 流通科学大学論集一人間・社会・自然編 Uournal of the University of Marketing and Distribution Sciences: Humanities, Arts \& Sciences], 30(2), 45-64. Retrieved from http://id.nii.ac.jp/1056/00001323/

Hamada, M. (2019, November). Exercises to boost self-esteem and self-realization. Paper presented at the JALT 2019 conference, Nagoya.

Hill, P. L. \& Turiano, N. A. (2014). Purpose in life as a predictor of morality across adulthood. Psychological Science, 25(7), 1482-1486. https://doi.org/10.1177/0956797614531799

Itazu, H. (1992). 生き方の研究一尺度構成と自己態度との関わりについて [A study on attitudes toward life: Constructing scales for self-attitude]. カウンセリング研究 [The Japanese Journal of Counseling Science], 25(2), 85-93.

Izumi, S., Ikeda, M. \& Watanabe, Y. (2012). CLIL (内容言語統合型学習): 上智大学外国語教育の新 たなる挑戦一第2巻実践と応用 [CLIL (Content and Language Integrated Learning): New challenges of foreign language education at Sophia University, volume 2: Practices and applications]. Tokyo: Sophia University Press.

Mehisto, P., Marsh, D., \& Frigols, M. J. (2008). Uncovering CLIL: Content and Language Integrated Learning in bilingual and multilingual education. London, England: Macmillan.

MEXT. (2006). キャリア教育推進の手引 [Guidance for promoting career education]. Retrieved from http://www.mext.go.jp/a_menu/shotou/career/070815/all.pdf

Moray, N. (1959). Attention in dichotic listening: Affective cues and the influence of instructions. Quarterly Journal of Experimental Psychology, 11(1), 56-60. https://doi. org/10.1080/17470215908416289 
Simons, D. J. \& Chabris, C. F. (1999). Gorillas in our midst: Sustained inattentional blindness for dynamic events. Perception, 28(9), 1059-1074. https://doi.org/10.1068/p281059

The Cabinet Office. (2014). 平成25年度 我が国と諸外国の若者の意識に関する調査 [International survey of youth attitudes 2013]. Retrieved December 23, 2019, from https://www8.cao.go.jp/youth/ kenkyu/thinking/h25/pdf_index.html

The Japan Association of National Universities. (2009). 大学におけるキャリア教育の在り方 [The current state of career education at Japanese universities]. Retrieved December 23, 2019, from http://www. janu.jp/active/txt6-2/ki0512.pdf

夢の実現へ信じる心育む「宝地図!描く [Treasure Map to grow self-confidence in realizing dreams] (2013, December 4). Chiba Nippo. Retrieved from https://www.chibanippo.co.jp/news/ local/169088

Uchida, T. (2014). ありがとうカウンター [Arigato Counter]. Osaka: SEIKO Press.

Watanabe, N. (2006). 7 つの習慣一小学校実践記 2 [The seven habits: Practice report 2]. Tokyo: King Bear Press.

Wilson, T. D. (2002). Strangers to ourselves: Discovering the adaptive unconscious. Cambridge, Mass: Belknap Press of Harvard University Press. https://doi.org/10.2307/j.ctvjghvsk

Yamamoto, M., Matsui, Y., \& Yamanari, Y. (1982). 認知された自己の諸側面の構造 [The structure of perceived aspects of self]. 教育心理学研究 [The Japanese Journal of Educational Psychology], 30, 6468. https://doi.org/10.5926/jiep1953.30.1_64

\section{Appendix A}

\section{Questionnaire}

日付: $\quad)$ 年( $)$ 月

学部、学科: )学部(

学年: $\quad$ )年生

名前: (

学籍番号: (

以下の各項目について、あなた自身にどの程度あてはまるかをお答えください。（他からどう見ら机 ているかではなく、あなたが、あなた自身をどう思っているかをありのままにお答えください。)アンケ 一ト結果は学術研究のための夕に用い、個人情報は決して公開いたしません。

\begin{tabular}{|c|c|c|c|c|c|}
\hline & 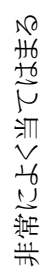 & 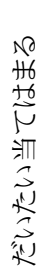 & 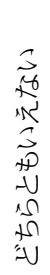 & 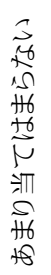 & 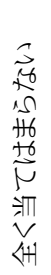 \\
\hline 1.少なくとも人並みには、価値のある人間である & 5 & 4 & 3 & 2 & 1 \\
\hline 2.色々な良い素質をもっている & 5 & 4 & 3 & 2 & 1 \\
\hline 3.物を人並みには、うまくやれる & 5 & 4 & 3 & 2 & 1 \\
\hline 4自分に対して肯定的である & 5 & 4 & 3 & 2 & 1 \\
\hline 5.だいたいにおいて、自分に満足している & 5 & 4 & 3 & 2 & 1 \\
\hline 6.自分は全くだめな人間だと思うことがある & 5 & 4 & 3 & 2 & 1 \\
\hline 7.努力をおしまずに、自分の出来ることに向かって完全燃焼する & 5 & 4 & 3 & 2 & 1 \\
\hline 8.自分の持っている潜在的可能性を追求しつづける & 5 & 4 & 3 & 2 & 1 \\
\hline 9.他者との関わりを大事にする & 5 & 4 & 3 & 2 & 1 \\
\hline 10.過去の失敗をくよくよ後悔しない & 5 & 4 & 3 & 2 & 1 \\
\hline 11.他人と争うようなことはしたくない & 5 & 4 & 3 & 2 & 1 \\
\hline 12.自分のやることに最善の努力を尽くす & 5 & 4 & 3 & 2 & 1 \\
\hline 13.もつと自分自身を尊敬できるようになりたい & 5 & 4 & 3 & 2 & 1 \\
\hline 14.自らを創造・開発していく & 5 & 4 & 3 & 2 & 1 \\
\hline $\begin{array}{l}\text { 15.何事も人間 } 1 \text { 人の力で出来るものではないから、お互いの協力 } \\
\text { を大事にする }\end{array}$ & 5 & 4 & 3 & 2 & 1 \\
\hline 16.何かに失敗しても混乱したり絶望したりしない & 5 & 4 & 3 & 2 & 1 \\
\hline 17.何かにつけて、自分は役に立たない人間だと思う & 5 & 4 & 3 & 2 & 1 \\
\hline 18.周囲の人と利害関係を離れた付き合いをする & 5 & 4 & 3 & 2 & 1 \\
\hline 19.時間は物を無駄にしない & 5 & 4 & 3 & 2 & 1 \\
\hline 20.将来に希望と期待をいだいている & 5 & 4 & 3 & 2 & 1 \\
\hline 21.他人には誠実な心を持って接する & 5 & 4 & 3 & 2 & 1 \\
\hline 22.事実をわだかまりなく、さっぱりと受け入れる & 5 & 4 & 3 & 2 & 1 \\
\hline 23.他人をないがしろにしない & 5 & 4 & 3 & 2 & 1 \\
\hline 24. 今という時を大切にする & 5 & 4 & 3 & 2 & 1 \\
\hline
\end{tabular}


Hamada: Exercises to Boost Self-Esteem and Self-Realization

\begin{tabular}{|c|c|c|c|c|c|}
\hline & 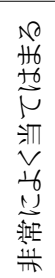 & 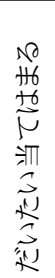 & 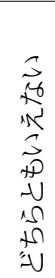 & 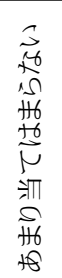 & 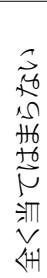 \\
\hline 25.敗北者だと思うことがよくある & 5 & 4 & 3 & 2 & 1 \\
\hline 26.自分のやるべきことは責任を持ってやり遂げる & 5 & 4 & 3 & 2 & 1 \\
\hline 27.自分自身にこだわりを持たない & 5 & 4 & 3 & 2 & 1 \\
\hline 28.自分の欲望のためには他人に迷惑をかけてもかまわない & 5 & 4 & 3 & 2 & 1 \\
\hline 29.義務や責任を進んで果たす & 5 & 4 & 3 & 2 & 1 \\
\hline $\begin{array}{l}\text { 30.自分のなかに好まない面を見つけたら、かくすよりも良くしてい } \\
\text { こうとする }\end{array}$ & 5 & 4 & 3 & 2 & 1 \\
\hline 31.自分には、自慢できるところがあまりない。 & 5 & 4 & 3 & 2 & 1 \\
\hline 32.出来るだけ多くの物事を見聞きしようとする & 5 & 4 & 3 & 2 & 1 \\
\hline 33.自分自身の行為に自信を持っている & 5 & 4 & 3 & 2 & 1 \\
\hline 34.何か自分の出来ることに専心する & 5 & 4 & 3 & 2 & 1 \\
\hline 35.何事にも興味と好奇心を持って接する & 5 & 4 & 3 & 2 & 1 \\
\hline 36.かけがえのない生命を精一杯生きる & & 5 & 4 & 3 & 2 \\
\hline 37.自分の良い面は否定せずに素直に受け入れる & 5 & 4 & 3 & 2 & 1 \\
\hline 38.何事も自分のことは自分でやる & 5 & 4 & 3 & 2 & 1 \\
\hline 38.英語が好きだ & 5 & 4 & 3 & 2 & 1 \\
\hline 39.英語が得意だ & 5 & 4 & 3 & 2 & 1 \\
\hline 40.英語力を向上させたい & 5 & 4 & 3 & 2 & 1 \\
\hline 41.英語学習に興味がある & 5 & 4 & 3 & 2 & 1 \\
\hline 42.これからの時代を生き抜くのに英語は必要だ & 5 & 4 & 3 & 2 & 1 \\
\hline
\end{tabular}

参考:

自尊感情尺度 (self-esteem): Q1-6, 13, 17, 25, 31 (逆転項目はQ13, 17, 25, 31) 生き方尺度 (attitudes toward life): Q7-12, 14-16, 18-24, 26-30, 32-38(逆転項目はQ28) 英語学習意欲に関する質問 (motivation for learning English): Q39-43

Appendix B

Gratitude List

あなたが今、感謝できる人物を日本語で書き出してみてください。 List all the people who you are grateful to.

\begin{tabular}{|l|l|l|}
\hline 例) (Mother) & & \\
\hline & & \\
\hline & & \\
\hline & & \\
\hline & & \\
\hline & & \\
\hline & & \\
\hline & & \\
\hline & & \\
\hline
\end{tabular}


2) あなたが今、感謝できることやものを日本語で書き出してみてください。 List what you can be grateful for.

\begin{tabular}{|l|l|l|}
\hline 例) 健康 (health) & & \\
\hline 日本が平和であること & & \\
\hline & & \\
\hline & & \\
\hline & & \\
\hline & & \\
\hline & & \\
\hline & & \\
\hline & & \\
\hline & & \\
\hline & & \\
\hline & & \\
\hline & & \\
\hline & & \\
\hline & & \\
\hline & & \\
\hline & & \\
\hline & & \\
\hline & & \\
\hline & & \\
\hline & & \\
\hline & & \\
\hline
\end{tabular}

3 ) 感謝リストに書きだしたものを英語になおしてみましょう。

Using the expressions below, write sentences in English.

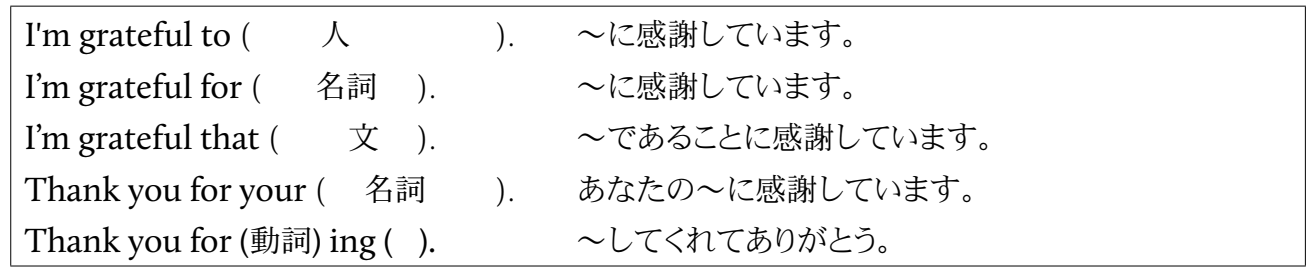

Ex.) I’m grateful to ( my parents ). 両親に感謝しています。

I’m grateful for ( my health ). 健康に感謝しています。

I’m grateful that ( I have a house to live in). 住む家があって感謝しています。

Thank you for ( your kindness ). あなたの親切に感謝しています。

Thank you for ( being my friend ). 私の友人でいてくれてありがとう。

$\begin{array}{ll}\text { 1) } & 12) \\ \text { 2) } & 13) \\ 3) & 14) \\ 4) & 15) \\ 5) & 16) \\ 6) & 17) \\ 7) & 18) \\ 8) & 19) \\ 9) & 20) \\ 10) & 21) \\ 11) & 22)\end{array}$




\section{Appendix C}

Twenty-Five Places I Plan to Visit

Ex.) I plan to visit ( New York ) and ( see the Statue of Liberty ) there.

\begin{tabular}{|c|c|c|}
\hline 1. I plan to visit ( & ) and ( & ) there. \\
\hline 2. I plan to visit ( & ) and ( & ) there. \\
\hline 3. I plan to visit ( & ) and ( & ) there. \\
\hline 4. I plan to visit ( & ) and ( & ) there. \\
\hline 5. I plan to visit ( & ) and ( & ) there. \\
\hline 6. I plan to visit ( & ) and ( & ) there. \\
\hline 7. I plan to visit ( & ) and ( & ) there. \\
\hline 8. I plan to visit ( & ) and ( & ) there. \\
\hline 9. I plan to visit ( & ) and ( & ) there. \\
\hline 10. I plan to visit ( & ) and ( & ) there. \\
\hline 11. I plan to visit ( & ) and ( & ) there. \\
\hline 12. I plan to visit ( & ) and ( & ) there. \\
\hline 13. I plan to visit ( & ) and ( & ) there. \\
\hline 14. I plan to visit ( & ) and ( & ) there. \\
\hline 15. I plan to visit ( & ) and ( & ) there. \\
\hline 16. I plan to visit ( & ) and ( & ) there. \\
\hline 17. I plan to visit ( & ) and ( & ) there. \\
\hline 18. I plan to visit ( & ) and ( & ) there. \\
\hline 19. I plan to visit ( & ) and ( & ) there. \\
\hline 20. I plan to visit ( & ) and ( & ) there. \\
\hline 21. I plan to visit ( & ) and ( & ) there. \\
\hline 22. I plan to visit ( & ) and ( & ) there. \\
\hline 23. I plan to visit ( & ) and ( & ) there. \\
\hline 24. I plan to visit ( & ) and ( & ) there. \\
\hline 25. I plan to visit ( & ) and ( & ) there. \\
\hline
\end{tabular}

